\title{
すき間腐食経由型応力腐食割れによる電位ノイズ
}

一社団法人腐食防食協会, 研究会「電気化学ノイズによる局部腐食の検出」(1995～1998） における共同実験結果の報告一*

\author{
井上博之**，大中紀之***
}

** 分科会「㫣気化学ノイスによる局部腐食の検出III」世話人, 大阪府立大学工学部

***研究会「電気化学ノイスによる局部腐食の検出 I・II」世話人, 日立協和エンジニアリング株式会社

\section{Potential Noise for Stress Corrosion Cracking in Corroding Crevice}

-Report on the Results of the Cooperative Experiment at the Working Group in Japan Society of Corrosion Engineering: "Detection of the Localized Corrosions by the Electrochemical Noise"-*

\author{
Hiroyuki Inoue ${ }^{* *}$, Noriyuki Ohnaka*** \\ - Chairman of the Working Group: "Detection of the Localized Corrosions by the Electrochemical Noise III", \\ College of Engineering, Osaka Prefecture University \\ *** Chairman of the Working Group : "Detection of the Localized Corrosions by the Electrochemical Noise I, II", \\ Hitachi Kyowa Engineering Co., Ltd.
}

\begin{abstract}
The working group in JSCE : "Detection of the localized corrosions by the electrochemical noise" carried out a cooperative measurement by the group members, to investigate the potential noises on the condition under which the cracks occurred in the corroding crevice. A crevice corrosion specimen with two type-304 stainless steel slips that were spot-welded in each other was used for the specimen. 3.5 mass $\% \mathrm{NaCl}$ solution at $80^{\circ} \mathrm{C}$ was employed under air exposed condition for the test solution. Potential noises were measured with an electrometer and a reference electrode every $0.5 \mathrm{~s}$ in typically.

From the measurement results, it was found a potential noise of a rapid shift to the noble side followed by slow recovery occurred in the condition under which the corrosion cracks were formed inside the crevice. This fluctuation pattern-calls RR-type-is a symmetrical to the pattern of the potential noise by localized corrosions that were formed on the free surface. The RR-type noise was not observed in the condition under which only the crevice corrosion occurred without the cracking.

To investigate the generation mechanism of the RR-type noise, the potential noise of the specimen was measured in scratching the specimen surface. And also, the short circuit current noise between the specimen and the counter electrode of type-304 stainless steel was measured in the same condition. Consequently, it was estimated the origin of the RR-type noise was hydrogen evolution reaction at the bare surface after the film breakdown by a crack formation, because cathodic local current, not anodic local current was required to make the potential shift noble side transitionally. The potential of inside a corroding crevice is a less noble level, and the $\mathrm{pH}$ in there is a lower value, so that hydrogen evolution reaction is easy to occur inside the crevice.
\end{abstract} current

Key words : noise, crack, type-304 stainless steel, neutral chloride solution, crevice, cathodic local

\section{1. 緒 \\ 言}

現場での応力腐食割れ（SCC）は, 自由表面ではな く,すき間内部を起点として発生することが少なくな

・第 124 回属食防食シンポジウム(京都, 1999 年) で発表

・テ 599-8531 堺市学園町 1-1 (1-1, Gakuen-cho, Sakai, 599-8531 Japan)

** \% 317-0072 日立市弁天町 3-10-2（10-2, Benten-cho, 3-chome, Hitachi, 317-0072 Japan)

社団法人度食防食協会，研究会「更気化学ノイスによる局部度食の検出」

\section{委昷}

明石正恒 (石川島播磨重工業)，井上博之*2 (大阪府立大学)，大中紀 之*1 (日立協和エンジニアリング), 高橋卓也 (日立製作所), 斎藤宣久 (東芝), 鈴木俊一 (東京電力), 田中良彦 (東京電力), 辻川茂男 (東京 大学), 水流 徹 (東京工業大学), 中山 元・2 (石川島播磨重工業), 酒 井潤一 (锄管計測), 藤本慎司 (大阪大学), 宮田恵守 (日本電信電話),

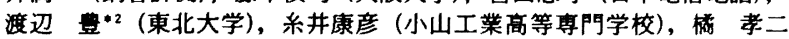
(東京理科大学), 宮澤正純 (三菱化学), 八代 仁 (岩手大学)

・1 : 世話人, $* 2$ : 幹事
い. 近年, 各種の材料や環境で, SCC による電気化学 ノイズ測定がおこなわれている。しかしながら,これ らの測定は, いずれも，自由表面にき裂や生起する際の ノイズ対象としている.そこで, 研究会「電気化学ノ イズによる局部腐食の検出」(以下「ENA 研究会」と する）では，ラウンドロビン測定（以下「共同実験」と する）をおこない，腐食しているすき間内部を起点とし てき裂が生起する（すき間腐食経由型 SCC が発生す る）際の電位ノイズについて検討した。その結果，すき 間内部を起点とする際にも, 自由表面を起点とする場合 と同じく, SCC が発生する条件下において特徵的な電 位ノイズが発生することが判明した。ただし，両者のノ イズ波形は, 定常の腐食電位に対して対称な変動パター ンを示した。

中性塩化物水溶液中では, 一般に, 自由表面での皮膜 破壊による電位ノイズは, 卑電位側へ急速に移行したあ と緩やかに回復する波形を有している(1)-4). 以下，この タイプのノイズ波形をRD 型（Rapid Drop followed 

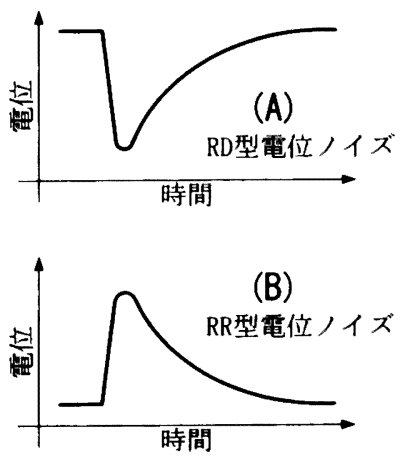

図 1 RD 型電位ノイズならびに RR 型電位ノイズの波形

by Slow Recovery, 図 1(A)) と呼ぶ。これに対して, すき間内部での新生面の露出（き裂生起）による電位， イズは，貴電位側へ急速に移行したあと緩やかに回復す る波形を示した。以下，このタイプのノイズ波形を $\mathrm{RR}$ 型 (Rapid Rise followed by Slow Recovery, 図 1(B)) あるいは L 型と呼ぶ。

本稿の前半では, ENA 研究会での共同実験結果をま とめる. 共同実験は, 1995 年から 96 年にかけて研究会 委員の所属する大学や企業でおこなわれた．また，本稿 の後半では, 研究会委員によって進められた，すき間腐 食経由型 SCC による電位ノイスの, 発生機構の検討結 果について紹介する。

\section{2. 共同実験の結果（すき間腐食経由型 SCC による電位ノイズ}

\section{1 実験方法}

共同実験には，スポット溶接したすき間付き試験片を 用いた。試験片の形状を図 2 に示す. $1 \mathrm{~mm}$ 厚の 2 枚の SUS 304 鋼片 $(20 \mathrm{~mm} \times 20 \mathrm{~mm}$ と $20 \mathrm{~mm} \times 50 \mathrm{~mm})$ を 重ねあわせ, 一対の直径 $4.5 \mathrm{~mm}$ の銅電極で挾み, $300 \sim 350 \mathrm{kgf}$ の荷重をかけ, 4.5 5.0 kA の電流で 10 サイクル通電した。試験片の材料には，メーカーで光輝 焼鈍された SUS 304 鋼を，受け入れままで使用した。 使用した 304 鋼の化学組成を表 1 に示す。以下，この試 験片を「共通試験片」と呼ぶ。スポット溶接部(ナゲッ 卜）の外周近傍には, 引張応力が残留している。このた め, 同試験片を適当な濃度・温度の塩化物水溶液中に浸 漬すると，すき間内のナゲット外周部を基点として，す き間腐食経由型のSCC が生じる。

共通試験片は, 測定前に, 外面を\# 400 以上まで機械 研磨した後, 重㭘わせ部を除きシリコンシーラントな どのシール材で被覆した。このタイプの試験片で，すき 間腐食経由型 SCC が生起する溶液条件は, 辻川らによ り詳細に検討されている5 . 共同実験では, SCC が確実

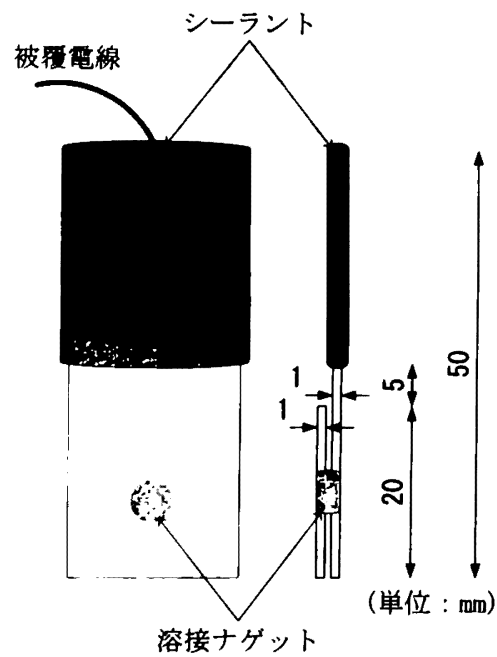

図 2 共同実験に使用した，スポット溶接すき間腐食試験片 (共通試験片)

表 1 共通試験片に用いた SUS 304 ステンレス鋼材料の化学組 成 (mass \%)

\begin{tabular}{|c|c|c|c|c|c|c|c|}
\hline $\mathrm{C}$ & $\mathrm{Si}$ & $\mathrm{Mn}$ & $\mathrm{P}$ & $\mathrm{S}$ & $\mathrm{Ni}$ & $\mathrm{Cr}$ & $\mathrm{Fe}$ \\
\hline 0.07 & 0.41 & 0.77 & 0.026 & 0.004 & 8.10 & 18.32 & balance \\
\hline
\end{tabular}

に生じる，大気開放した $80^{\circ} \mathrm{C} の 3.5$ mass $\% \mathrm{NaCl}$ 水溶 液を標準条件とした。ただし，機関によっては，比較の ため,すき間腐食のみが生じる条件 $\left(40^{\circ} \mathrm{C}\right.$ の 3.5 mass $\% \mathrm{NaCl})$ での測定も試みられた。各機関で用いられた 条件を表 2 にまとめる。

測定対象は, 原則として, 自然浸漬状態における電位 ノイズとした。電位ノイズ法は, 他の電気化学ノイズ法 と比較し，(1)溶液中に溶存酸素などの酸化郕が相当量 が含まれていたとしても，充分なノイス信号強度が確保 できる（2）ポテンショスタットを使用しないために高 精度の測定が容易におこなえる息などの利点を有してい る.このため, 各種ノイズ法の中で, 最も腐食モニタリ ングへの展開が容易と考えられている.

電位ノイズ法は, 試験片の腐食電位を, 入力抵抗の高 いデジタル電圧計などを用いて，一定間隔で連続測定す る. 研究会では，(1) $100 \mu \mathrm{V}$ 以上の精度, (2) 1 秒以下 の測定間隔を, 推奨条件として定めた。一例として, 図 3 に, 大阪府立大学山川研究室で用いられた測定系の概 念図を示す。山川研究室では, $1.2 \mathrm{~V}$ レンジで最小析 1 $\mu \mathrm{V}$ のデジタル電圧計を用いて, 試験片と銀・塩化銀参 照電極の電位差を, 0.5 秒間隔で測定して電位ノイズ波 形を得た。測定されたデータは、デー夕数が 4096 点 (約 34 分間) に達するまで電圧計の内藏メモリに蓄えら れ，その後，GP-IB バスを通じてパソコンへ転送しハ

表 2 共同実験に参加した各機関で用いられた試験溶液

\begin{tabular}{|c|c|c|c|c|c|c|}
\hline 機関名 & 大阪府立大学 & 東北大学 & $\begin{array}{c}\text { 石川息播磨 } \\
\text { 重工業 }\end{array}$ & 東芝 & 日立製作所 & 鎆管計測 \\
\hline 液温 $\left({ }^{\circ} \mathrm{C}\right)$ & $80,60,40$ & 80 & 80 & 80 & 80 & 80 \\
\hline $\mathrm{NaCl}$ 灌度 $(\%)$ & 3.5 & 3.5 & $3.5,0.35$ & 3.5 & 3.5 & 3.5 \\
\hline
\end{tabular}




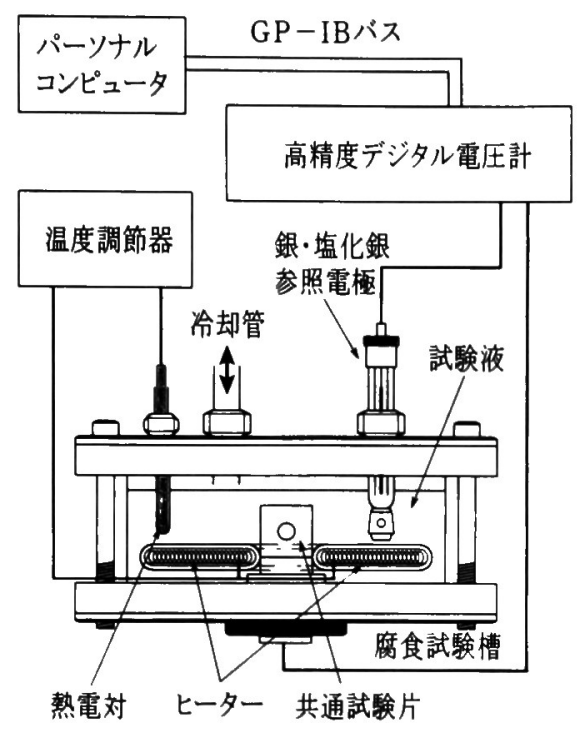

図 3 電位ノイズ測定系の一例

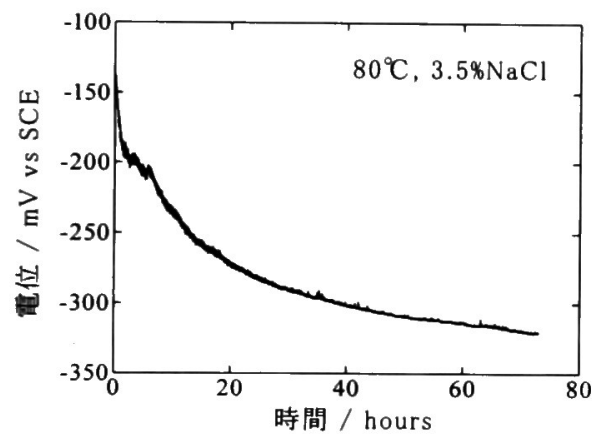

図 4 標準条件（3.5 mass \% NaCl 水溶液）に自然浸漬された 共通試験片のマクロな腐食電位変化 ${ }^{7}$

ードディスクに保存された。この電位測定とディスクへ の保存の操作を, 自動で連続して繰り返しおこなった.

\section{2 実験結果}

図 4 に, 標準条件 $\left(80^{\circ} \mathrm{C}, 3.5\right.$ mass \% NaCl) にお ける腐食電位のマクロ変化（ノイズではない平均の腐食 電位の変化）の一例を示す7). 腐食電位は, 浸漬開始後 数分以内にー $150 \mathrm{mV}$ (vs. SCE) 以上にまで上昇したあ と, 放物線状に電位が低下し，約 48 時間後には -300 $\mathrm{mV}$ 以下にまで至った。この変化傾向は, 同じ条件でお こなわれた他の結果においても同一であった．標準条件 における共通試験片のすき間腐食再不働態化電位 $\left(E_{\mathrm{R}, \mathrm{Crev}}\right)$ が約 $-250 \mathrm{mV}$ )であること, ならびに, 浸漬 開始後数時間で, 試験片すき間部から腐食生成物の渗出 が認められたことから，この電位低下は，すき間腐食電 流の増加によってもたらされたと考えられる。試験終了 後に,すき間内面の状態を観察するために, 試験片の溶 接ナゲット部にバイトで貫通孔を空けて，接合された鋼 片を分離した. その結果, すき間内面の大部分で均一な 腐食（すき間腐食）が生じていた。 また，ナゲット外周 部には，多数のき裂が生成していた．図 5 の(a)と(b) に,それぞれ，同じ条件で浸漬された試験片の，ナゲッ

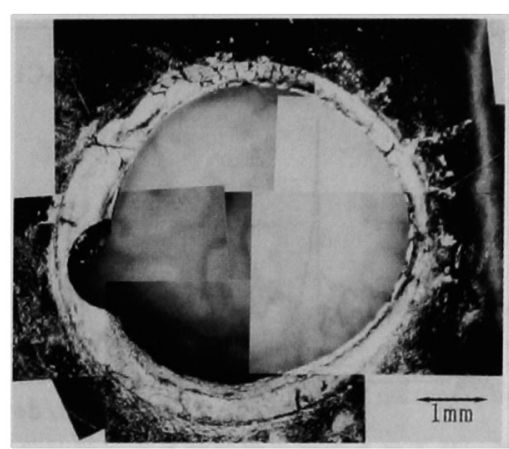

(a)

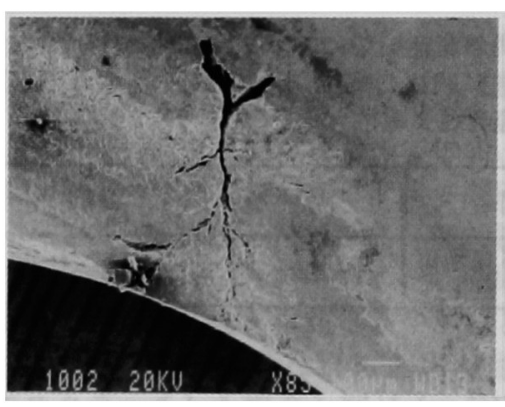

(b)

$\overline{200 \mu \mathrm{m}}$

図 5 標準条件に自然浸漬された共通試験片の, 試験後のすき 間内部側の溶接ナゲット外周部のマクロ写真 $(\mathrm{a})^{8)}$ ならび に，同部分で発生したき裂の SEM 写真 $(\mathrm{b})^{8)}$

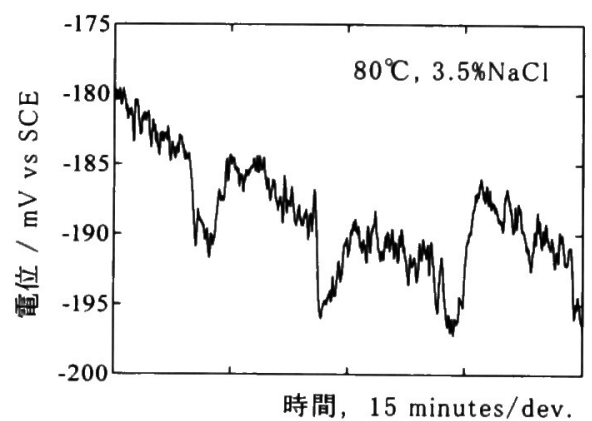

図 6 図 4 に示した結果において, $-200 \mathrm{mV}$ (vs. SCE) より貴な 電位域で観測された電位ノイズの典型例7)

ト外周部のマクロ写真ならびに，き裂が発生している部 分の SEM 写真を示す. なお, 浸漬時間を長くした試験 片では，すき間部の外面側にも，き裂が生じていた。き 裂が存在している箇所の裏側（内面）には, 例外なく発 達した腐食き裂が確認された。したがって，外面のき裂 は, 外面側より生じたのではなく, 内面側を起点として 進展・貫通したと判断される ${ }^{8)}$.

図 6 ならびに 7 に, 図 4 の腐食電位に重畳していた電 位ノイズの典型例を示す7). $-200 \mathrm{mV}$ (vs. SCE) 以上の 電位域 (実験時間の前半) では，図 6 に示した，卑側に 急速に移行したあともとの電位に回復する RD 型の電位 が観測された。これに対して, $-200 \mathrm{mV}$ 以下の電位域 （実験時間の後半）では, 逆に, 図 7 に示した, 貴側に 移行したあと回復する RR 型（L 型）の電位ノイズが観 測された，機関によって，波形が変化する臨界電位の值 


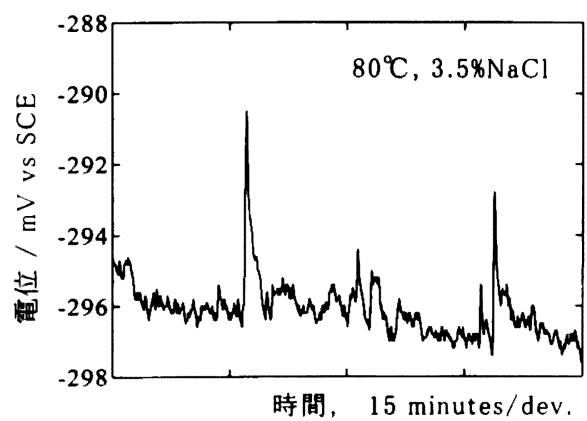

図 7 図 4 に示した結果において, $-200 \mathrm{mV}$ (vs. SCE) より卑な 電位域で観測された電位ノイズの典型例7)

表 3 各機関の測定結果における，標準条件下で自然浸湞され た共通試験片の電位ノイスか，RD 型から RR 型へ遷移 する臨界腐食電位

\begin{tabular}{|c|c|c|c|}
\hline 機関名 & $\begin{array}{c}\text { 大阪府立 } \\
\text { 大学 }\end{array}$ & $\begin{array}{c}\text { 石川岛播磨 } \\
\text { 重工業 }\end{array}$ & 東芝 \\
\hline $\begin{array}{c}\text { 臨界腐食電位 } \\
(\mathrm{mV} \text { vs SCE })\end{array}$ & 約 $-220 \mathrm{mV}$ & 約 $-260 \mathrm{mV}$ & 約 $-250 \mathrm{mV}$ \\
\hline
\end{tabular}

に多少のばらつきはあった（表 3 ）ものの，いずれの機 関の結果でも，RR 型ノイズの発生が確認されている。

$R R$ 型ノイスの発生条件を検討するために，標準条件

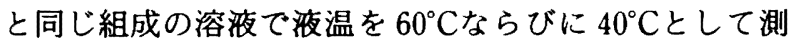
定をおこなった。 $80^{\circ} \mathrm{C}$ (標準条件)における結果を含 め, それぞれの液温におけるマクロな腐食電位の変化を

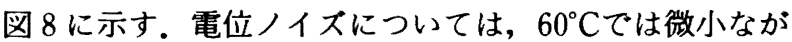

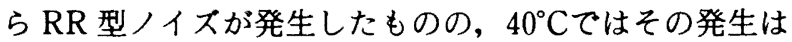
全く認められなかった．測定後にすき間内部の溶接ナゲ

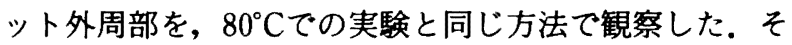

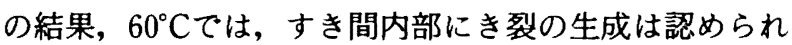
たものの, $80^{\circ} \mathrm{C} て ゙ の$ 同筒所の状態と比較すると, 発生数 が少なく，表面でのき裂長さも短かった。また， $40^{\circ} \mathrm{C} て ゙$ は，軽微なすき間腐食のみが生じており，き裂の発生は 認められなかった。さらに，共通試験片と同じ材料から 平板（すき間やスポット溶接部がない）試験片を作成 し，標準条件下で電位ノイスを測定したが，RR 型ノイ スの発生は認められなかった。また，共通試験片のすき 間部にエポキシ樹脂を充填した試験片についても，標準 条件下で電位ノイスの測定をおこなったが，同じく $\mathrm{RR}$ 型ノイズは認められなかった。

\section{3. 新生面の露出と RR 型電位ノイス発生との 相関の確認}

共同実験の結果より， 3.5 mass $\% \mathrm{NaCl}$ 水溶液中に 304 鋼の試験片を浸漬させた場合，すき間腐食経由型の $\mathrm{SCC}$ が生じる条件下においてのみ, RR 型の電位ノイ スが発生することが明らかとなった。しかし，一般に は, 中性塩化物水溶液中でのステンレス鋼の局部腐食発 生による電位ノイスは， RR 型ではなく RD 型となる ${ }^{3,4}$ (図 1)。これまでも， $\mathrm{CO}-\mathrm{CO}_{2}-\mathrm{H}_{2} \mathrm{O}$ 環境中での炭素 鋼9や酸性塩化物水溶液中での析出硬化型ステンレス 鋼(10)では，応力腐食割れの生起に対応して，RR 型電位

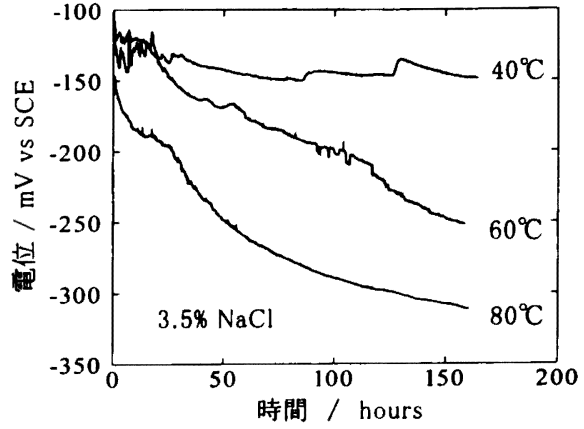

図 880,60 ならびに $40^{\circ} \mathrm{C} の 3.5$ mass \% $\mathrm{NaCl}$ 水溶液中に漫 漬された共通試験片のマクロな腐食電位変化

ノイズが発生するとの報告があった。しかしながら，共 同実験で使用した，中性塩化物水溶液中で $\mathrm{RR}$ 型のノイ ズが観察された例は皆無であった。これは，従来，中性 塩化物水溶液中での局部腐食による電気化学ノイズの研 究が，いずれも，すき間腐食経由型ではなく，自由表面 からの食孔やき裂の生成を対象としてきたことによると 考えられる。

ところで，先に述べたと扔り，RR 型電位ノイズが発 生する条件下では，すき間腐食とき裂生成が同時に生じ ている。したがって，RR 型のノイズの発生源は，必ず しも初期き裂の生成による新生面の露出ではなく，すき 間腐食電流のゆらぎである可能性も否定できない．系井 らは, すき間腐食が進行しているアルミニウムでは, 水 素ガスの発生に起因して電流ノイズが発生することを報 告している ${ }^{11}$. 第 2.2 節で述べたとおり, 浸漬した共通 試験片にすき間腐食のみが生じる，40ㄷ 3.5 mass \% $\mathrm{NaCl}$ 水溶液では, $\mathrm{RR}$ 型の電位ノイスは発生しなかっ た。しかしながら， $60 \sim 80^{\circ} \mathrm{C}$ と液温を上昇させるにした がってガス発生が加速され, 電位ノイスの発生が顕在化 した可能性もある。そこで，RR 型の電位ノイズが, $\mathrm{RD}$ 型の場合と同じく，皮膜の破壊（新生面の露出）に よって生じたことを確認するための実験がおこなわれ た.

井上らは，共同試験と同じ条件下で，電位ノイスをを測 定しながら, 試験片外面をスクラッチした ${ }^{22}$. つまり, すき間腐食が生じている試験片で，表面皮膜の破壊が生 じた際に，どのような形状のノイスが発生するかを検討 した。図 9 の(a), (b), (c)ならびに(d)に，共通試験片 あるいは平板の外面をスクラッチした際に発生した電位 ノイスの典型例を示す。いずれの結果とも，スクラッチ は，図中の矢印の時点でおこなわれた。標準条件 $\left(80^{\circ} \mathrm{C}\right.$ の $3.5 \mathrm{mass} \% \mathrm{NaCl}$ 水溶液中）で共通試験片をスクラ ッチした場合には，図 7 の結果と同じく, RR 型の電位 ノイズが発生している（図9の(a)).これに対して, 自然浸漬状態では RR 型ノイズが発生しなかった，標準 条件中での平板試験片や $40^{\circ} \mathrm{C} て ゙ の$ 共通試験片の場合は, スクラッチにより RD 型の電位ノイズが発生した（図 9 の (d)ならびに(c))。また，標準条件で自然浸漬させた 試験片と比較すると，き裂の数や表面長さが短かった $60^{\circ} \mathrm{C} て ゙ は ，(a) に$ 示した結果よりはやや振幅が小さいも のの, 同じく RR 型ノイズの発生が認められた（図 9 の (b)). 

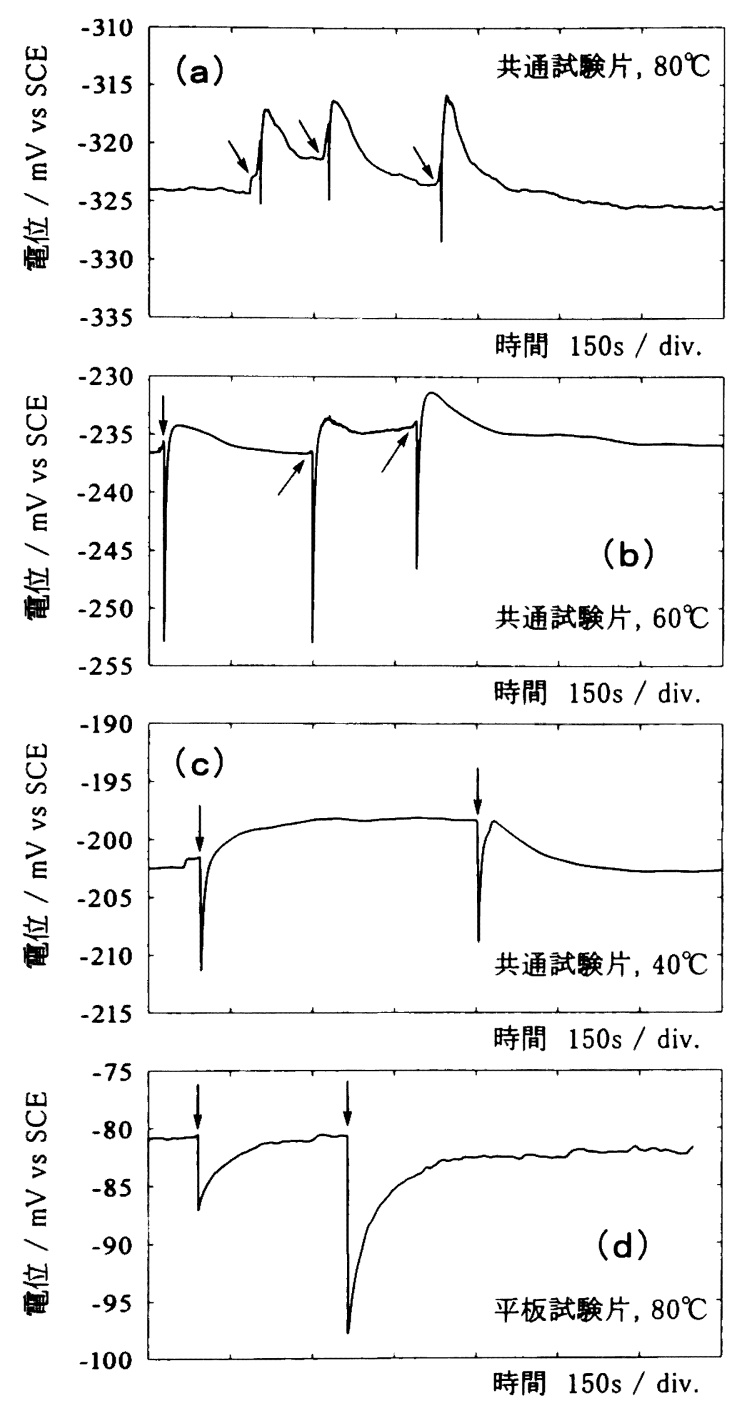

図 9 種々の温度条件下で共通試験片ならびに平板試験片の外 面を, セラミックス棒でスクラッチした際の電位ノイス (図中に矢印で示した時点において，それそれ，1回ず つ、スクラッチをおこなった.）

図 9 の (a)と (d)は, 環境条件は同一であるが, 前者 は共通試験片を, 後者は平板を試験極に用いていること から, 浸溑電位は(d)の結果の方が $200 \mathrm{mV}$ 以上高い. つまり, 試験片の腐食電位が, すき間腐食経由の SCC が発生する電位条件にある場合にのみ, 試験片表面にひ つかきを与える（新生面を露出させる）と RR 型のノイ スが発生するものと推察される，中山らは，すき間腐食 を発生させた無負荷の丸棒試験片に, 急速に引張荷重を 与え，その際に発生する電位ノイズを測定した7). 結果 を図 10 に示す. 荷重（ひずみ）の付与に同期して，図 6 に示した結果と相似な RR 型の電位ノイズが発生して いる.

上記の確認試験は，いずれも，すき間外部の表面皮膜 を破壞した際の結果であり，すき間内部での新生面の露 出（き裂発生）によるノイズを，直接的に評価したもの ではない. しかしながら，第 4 節で述べるとおり， RR 型ノイスの信号源は, 新生面の露出部での水素発生反応 による局部カソード電流と考えられる，腐食が進行して

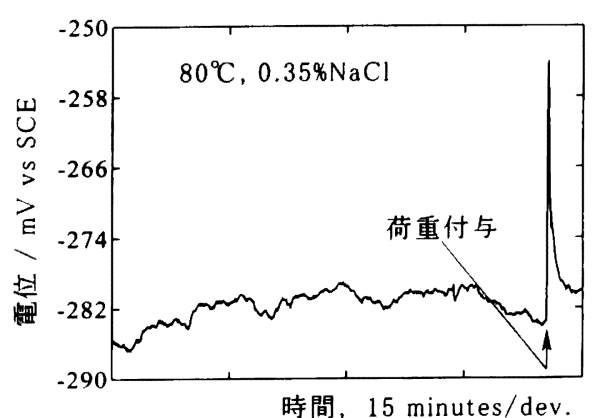

図 10 無負荷状態ですき間腐食を発生させておいた丸棒試験片 に，急速に引張荷重を与えた際のミクロな腐食電位変 化 ${ }^{7}$

いるすき間内の溶液の $\mathrm{pH}$ は, 溶出金属イオンの加水分 解により，バルク溶夜よりも低くなっている。 また，腐 食しているすき間内部の電極電位は，すき間内部から外 部へのアノード電流の IR ドロップにより, 試験片全体 の腐食電位よりも低い. したがって，すき間内部の方 が，外部よりも水素発生反応は起こりやすいと考えられ る.つまり，すき間内部で新生面の露出が生じた際に も，外面をスクラッチした場合と同じく, $\mathrm{RR}$ 型電位ノ イズが発生すると推察される。

\section{RR 型電位ノイズの発生機銝}

自然浸漬状態において，不働態化している金属の表面 では, 不働態保持電流 $i_{\mathrm{p}}$ とカソード反応電流 $i_{\mathrm{c}}$ がつり あっており，同状態での腐食電位は， $i_{\mathrm{p}}$ ならびに $i_{\mathrm{c}}$ の 分極曲線の交点となる．カソード反応は，共同実験の標 準条件のような，大気開放された中性環境中では溶存酸 素の還元反応となる。試験片表面で皮膜破壊が起こる と, 破壊箇所での局部アノード電流 $i_{\mathrm{a}}{ }^{\prime}$ が不働態保持電 流 $i_{\mathrm{p}}$ に加算されるため, アノード部分分極曲線は高電 流側へ移動し $\left(i_{\mathrm{p}} \rightarrow i_{\mathrm{p}}+i_{\mathrm{a}}{ }^{\prime}\right)$, 腐食電位は卑側へ移動す る.アノード反応の増加により生じる電子は, カソード 反応 (溶存酸素の還元反応), あるいは皮膜容量の放電 によって消費される．前者の電気化学モデルをファラデ イックモデル, 後者のそれをノンファラディックモデル と呼ぶ(4). 局部アノード電流が増加すると, ファラディ ックモデルでは, 腐食電位はカソード部分分極曲線にそ って早側へ移行する．また，同じくノンファラディック モデルでは, 電位は皮膜容量の放電量に応じて卑側へ移 行する2).4).つまり，いずれのモデルに従うにせよ，電 極が不働態化された状態（アノード反応律速下）におい て, 皮膜破壊によって局部アノード電流が生じると, 発 生する電位ノイズの波形は RD 型となる.

図 9 の(a)ならびに(b)に示した結果に見られるとお り,すき間腐食経由型 SCC が発生する電位条件下て は, 不働態金属の表面をスクラッチすると, RD 型とは 対称な変動パターンを有する，RR 型のノイズが発生す る.スクラッチにより貴側へ電位が移行するノイズが発 生するためには, ノンファラディック・ファラディック のいずれのモデルに従うにせよ, 新生面の露出によって 生じる局部電流は, アノード電流ではなく，カソード電 


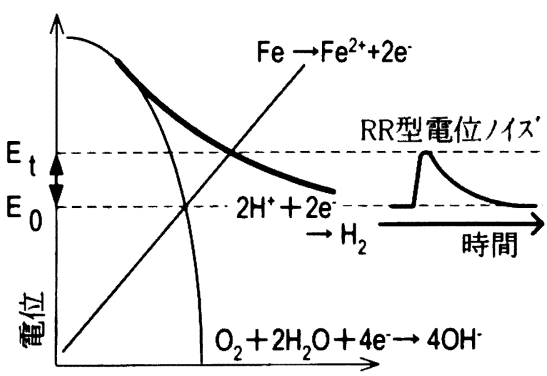

Log 電流

図 11 局部電流の対反応が，ファラディックな反応によって担 われていると仮定した場合の, カソード限界電流の変化 と電位ノイズ波形の関係

流でなければならない．新生面は化学的活性が高いこと から，アノード溶解反応だけではなく，カソード還元反 応の速度も大きいと推定される。.また，電極面における 水素発生の速度は, 一般に電極電位が低いほど大きい. 激しいすき間腐食を生じている試験片では，すき間部か らの大きなアノード電流により, 試験片の腐食電位は卑 側にシフトしている。 このため, 新生面での水素の発生 （還元反応）速度が金属イオンの溶出（酸化反応）速度 を上回り，過渡的に電位が貴側へ移行し，RR 型のノイ ズが生じたと推測される。ささらに，第 3 節で述べたとお り，腐食しているすき間内部の電位は外部よりも卑であ り, 溶液の $\mathrm{pH}$ は低い。したがって, 自然浸漬されたす き間付き試験片では，すき間内部の方が外部よりも，水 素発生反応は生じやすいと考えられる。

すき間腐食が進行している試験片では, 一般に, カソ 一ド反応（溶存酸素の還元反応）は限界電流に達してい る.ここで, 新生面において局部カソード電流が生じる と, その分たけ, 試験片全体でのカソード限界電流 $\left(i_{1 \mathrm{~m}}\right)$ は高電流密度側へ拡張される $\left(i_{11 \mathrm{~m}} \rightarrow i_{11 \mathrm{~m}}+i_{\mathrm{c}}{ }^{\prime}\right)$. このカソード電流増加に必要な電子は, ファラディック モデではすき間腐食電流の増加によって, ノンファラ ティックモデルでは界面容量への充電によって供給され る.ファラディックモデルが成立する際の, カソード限 界電流の変位と電位ノイス波形の関係を図 11 に示す。 なお，本実験結果の範囲内では，その比率について明ら かにはできないものの, 局部電流の対反応は, 自由表面 での皮膜破壊の場合と同じく, ファラディックならびに ノンファラディックな反応機構が, 一定の割合で組み合 わさっているものと推測される131.

土屋と斎藤は, 約 $-100 \mathrm{mV}$ から $-400 \mathrm{mV}$ (vs. SCE) の電極電位において, 新生面の露出により局部アノード 電流・カソード電流のいずれが生じるのかを検討し た ${ }^{14)}$. 彼女らは, 平板 304 鋼の試験極に, 同じ材料で作 成された種々の形状（平板や共通試験片，Uベンド試 験片）の対極を短絡することにより, 試験極の電位を任 意の值に制御した。そして, その状態において, 試験極 をスクラッチし，短絡電流ノイズならびに電位ノイズを 測定した。結果の典型例を図 12 と 13 に示す。いずれの 図においても，矢印がスクラッチをおこなった時点を示 す。また，電流の符号は試験極から対極側へ流九る（試 験極が酸化される) 方向を正としている. 定常の腐食電 位が高い $(-160 \mathrm{mV}$ vs. SCE 近傍) の場合には, スク

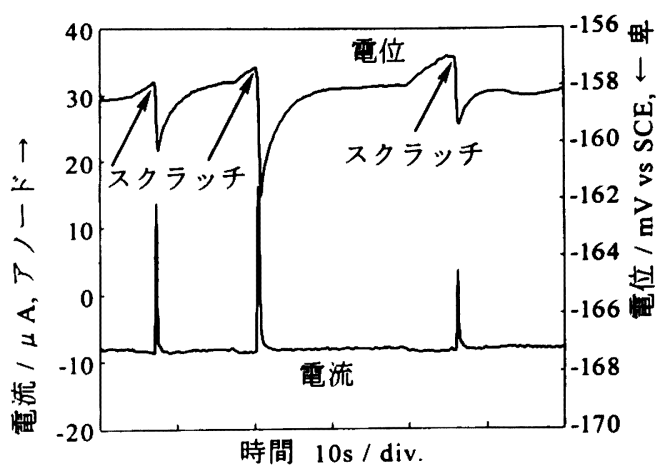

図 12 腐食電位が比較的高い条件下で試験片をスクラッチした 際の, 試験片の腐食電位ならびに対極との短絡電流の変 化 ${ }^{14}$

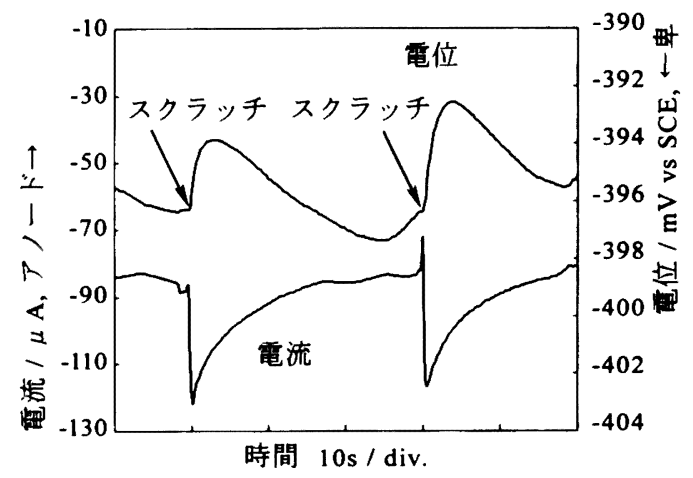

図 13 腐食電位が比較的低い条件下で試験片をスクラッチした 際の, 試験片の腐食電位ならびに対極との短絡電流の変 化 ${ }^{(4)}$

ラッチにより生じた電位ノイスの波形は RD 型であり， 対応する短絡電流はアノード電流となる（図 12）。つま $\eta, \mathrm{RD}$ 型の電位ノイズが発生する条件下では, 新生面 の露出により局部アノード電流が生じると考えられる. これに対し，腐食電位が低い $(-390 \mathrm{mV}$ vs. SCE 近傍) 場合には，電位ノイスの波形は RR 型となり，対応する 短絡電流はカソード電流となっている(図 13)。つま $\eta, \mathrm{RD}$ 型の場合と対照的に, 新生面での局部電流は, トータルとしてはカソード電流となっていると考えられ る.

\section{5. まとめならびに今後の課題}

共同実験結果より，スポット溶接されたすき間付き 304 鋼試験片を中性塩化物水溶液中に浸漬させると, す き間腐食部でき裂が生成している，あるいは生成しつつ ある条件下では， RR 型の電位ノイズが発生した。スク ラッチ試験や短絡電流の測定結果から，すき間腐食によ り卑側へ腐食電位がシフトした状態では，皮膜破壊によ り局部カソード電流が生じることが明らかになった。こ れは，すき間腐食により電極電位が低くなったため，新 生面での水素発生反応が加速され, 同箘所におけるカソ 一ド電流が,アノード電流を上回ったことから, 局部力 ソード電流が生じたと推測される．スクラッチ試験や短 絡電流測定では,すき間内部ではなく外面に新生面を生 成させた。しかし，すき間内部の電極電位や溶液の $\mathrm{pH}$ 
は，外部よりも低いことから，すき間内部でき裂発生 （新生面の露出）が生じた場合には，より水素発生反応 が生じやすく， RR 型ノイズが発生しやすいと推察され る. しかしながら, 新生面での水素発生反応について は, 現時点では, 単なる推測の域を出ていないと言え る. 今後は, 新生面上でのカソード反応の種類を, 実験 的に明らかにする取り組みが必要と考えられる。

共通試験片を用いた測定では，すき間腐食経由型の割 れが生じる条件下での, RR 型ノイズの振幅は約 $10 \mathrm{mV}$ 以下であった。これは，自由表面から孔食中やき裂生 成 ${ }^{15)}$ における RD 型ノイズの 10 分の 1 から 30 分の 1 以下にすぎない.したがって, 信号強度の点から, 共通 試験片を用いて実環境てのモニタリングをおこなうこと は困難であると言える。今後は, 最適な外面とすき間内 部の面積比について検討をおこない，よりノイズの振幅 が大きくなるすき間付き試験極を開発する必要がある.

$\mathrm{RD}$ 型電位ノイズについては, 逆電位設定法)などを 用いることにより，ノイズ波形から対応する局部溶解量 を推定することができる。しかしながら，RR型ノイズ の場合には，ノイス波形から，対応する局部溶解量（微 小き裂の大きさ）を定量的に推定する手法は確立されて いない. したがって, 電位ノイズ測定の結果から, 現在 の環境条件が，き裂発生の臨界条件の近傍にあることを 推測することは可能であるが, どの程度その臨界条件か ら離れているかを定量的に知ることはできない．今後 は, 自由表面での皮膜破壊による電位ノイズ (RD 型) と同じく、観測されたノイズ波形から，対応する局部溶 解量を推定する手法を検討していく必要がある.

\section{6. 結言}

スポット溶接されたすき間付き 304 鋼試験片を，大気 開放された中性塩化物水溶液中に浸漬させたところ,

（1）すき間腐食経由型 SCC が発生する，あるいは 発生しつつある条件下では, 電位が貴側へ急速に移行し たあと緩やかに回復する（RR 型あるいは L 型と呼ふ）

電位ノイスが発生した。

（2）局部腐食が生じないあるいはすき間腐食のみが 生じている条件下では，RR 型の電位ノイスは発生しな かった。

（3）電極電位が(1)の電位条件下にある試験片表面を スクラッチし, 皮膜の局部を破壊すると, RR 型の電位 ノイスが発生した。

（4）電極電位が(2)の電位条件下にある試験片表面を 同じくスクラッチすると, $\mathrm{RD}$ 型の電位ノイズが発生し た。

（5） RR 型電位ノイスに対応する局部電流はカソー ド電流であり， RD 型ではアノード電流であると考えら
れる.

（6） RR 型電位ノイズの発生する電位条件下では, 新生面での水素発生速度が大きいために, 同䇢所での電 流は,トータルとしては局部カソード電流となったもの と推測される。

\section{謝 辞}

共同実験用の試験片（共通試験片）を作成するにあた り，ENA 研究会委員の所属企業よりご援助を賜った。 記して感謝の意を表する。

\section{文献}

1) T. Hagyard and J.R. Williams: Trans. Faraday Soc., 57, 2295 (1961)

2) H.S. Isaacs and Y. Ishikawa : J. Electrochem. Soc., 132, 1288 (1985)

3) M. Hashimoto, S. Miyajima and T. Murata : Corros. Sci., 33, 885 (1992)

4) 井上博之, 山川宏二, 菊池輝親, 米田 裕 (H. Inoue, K. Yamakawa, T. Kikuchi and Y. Yoneda) : 材料と環 境 [Zairyo-to-Kankyo (Corros.Eng.) ], 45, 717 (1996).

5）梁成浩, 策原正, 辻川茂男 (C. Liang, T. Shinohara and S. Tsujikawa) : 防食技術 [Boshoku-Gijutsu (Cor ros.Eng.) ], 38, 650 (1989)

6) 井上博之, 山川宏二：電気化学, 66, 1076 (1998)

7) 中山 元, 明石正恒, 井上博之, 山川宏二 (G. Nakayama, M. Akashi, H. Inoue and K. Yamakawa) : 第 113 回腐食防止シンポジウム資料（Proc. 113th Corros, Eng. Symposium), p.38，腐食防食協会（JSCE）（1997）。

8）渡辺 豊：未発表デー夕

9) H.J. DeBruyn, K. Lawson and E.E. Heaver : "Electrochemical Noise Measurement for Corrosion Applications, STP 1277", Ed. by J.R. Kearns, J.R. Scully, P.R. Roberge, D.L. Reichert and J.L. Dawson, p.214, ASTM, West Conshohocken (1996)

10) J. G. Gonzalez-Rodriguez, V. M. Salinas-Bravo, E. Garcia-Ochoa and A. Diaz-Sanchez: Corrosion, 53, 693 (1997)

11) 采井康彦，奥山優 (Y. Itoi and M. Okuyama)：第 113 回腐食防食シンポジウム資料（Proc. 113th Corros. Eng. Symposium)，p.58，腐食防食協会（JSCE）（1997）。

12）井上博之, 山川宏二, 松尾元樹 (H. Inoue, K. Yamakawa and M. Matsuo)：第 43 回腐食防食討論会講演集 (Proc. 45th Japan Conf. Materials and Environments), p.537，腐食防食協会（JSCE）（1996）。

13）井上博之, 山川宏二, 田中安栄 (H. Inoue, K. Yama kawa and Y. Tanaka): 材料と器境 '97講演集 (Proc. JSCE Materials and Environments 1997), p.45，腐食防 食協会 (JSCE) (1997).

14）土屋由美子, 斉藤宣久 (Y. Tsuchiya and N. Saito)：材 料と渨境'98 講演集 (Proc. JSCE Materials and Environments 1998), p.113，腐食防食協会（JSCE）（1998）。

15）井上博之, 山川宏二, 米田裕 (H. Inoue, K. Yamakawa and Y. Yoneda)：第 43 回腐食防食討論会講演集 (Proc. 45th Japan Conf. Materials and Environments), p.539，腐食防食協会（JSCE）（1996）。

（1999 年 11 月 4 日受理） 